\title{
Going 3D with Technology: An Overarching Approach for Language Teachers
}

\section{La introducción a la tecnología en 3D: Un Enfoque Global para Profesores de Lenguas}

Jason D. Hendryx ${ }^{1}$

Citation/ Para citar este Artículo: Hendryx J. (2016). Going 3D with Technology: An Overarching Approach for Language Teachers. Colomb.Appl. Linguist.J. 18(1), pp 133-140

Received: 18-Dec-2015 / Accepted: 01-Apr-2016

DOI: http://dx.doi.org/10.14483/calj.v18n1.9884

\begin{abstract}
Grounded in over a decade of language classroom observations, in multiple institutions of secondary and higher education in several countries, across over a dozen languages, three key features of what appear to be successful applications of technology by instructors in these classes for language teaching emerged. These features came to be identified as directional, developmental, and decisive-hereafter referred to as the 3Ds. Observational data suggests that when an instructor embraces any of the 3Ds while using technology for teaching and learning purposes, the more successful that application of technology seems to be. Success here should be understood as higher levels of student interaction, engagement, and motivation, with more kinds and types of student language being produced. Meanwhile, observations of instructors who did not utilize any of the 3Ds, revealed stiff, uninspiring uses of technology, oftentimes devoid of context, which did not result in much, if any, student interaction or language production.
\end{abstract}

Key words: language teaching, teacher development, teaching approaches, technology

\section{Resumen}

Después de más de una década de observaciones en clases de más de una docena de idiomas, en múltiples instituciones de educación secundaria y de educación superior en varios países, se puede afirmar que existen tres usos pedagógicos clave para una introducción exitosa de la tecnología por parte de los profesores. Los tres usos identificados son: direccional, de desarrollo, y crítico. En lo sucesivo, llamados usos 3D. Los datos de observación obtenidos sugieren que cuando un profesor de idiomas introduce la tecnología en el aula por medio de cualquiera de los tres usos indicados, incrementa el éxito de resultados. El éxito aquí debe entenderse como un mayor nivel de interacción, de motivación, de compromiso y de producción de lenguaje por parte de las estudiantes. Mientras tanto las observaciones de profesores que introducen la tecnología en el aula sin tener en cuenta los usos 3D, revelaron aplicaciones rígidas y aburridas de los medios tecnológicos para la enseñanza y el aprendizaje de lenguas. Dichas aplicaciones muchas veces se caracterizan por desdeñar el contexto pedagógico de manera que generan entre los estudiantes escasos o nulos niveles de interacción o de producción de lenguaje.

Palabras clave: enseñanza de lenguas, desarrollo docente, enfoques de enseñanza, tecnología

1 University of Wyoming. United States jhendryx@uwyo.edu 


\section{Introduction}

We live in interesting times as language teachers. The concepts of distance, language, and time have been dramatically altered by technology in recent decades. Such changes are made evident by the various forms and kinds of living language and realia we now have access to through technology which we can utilize to teach languages. It is now not only conceivable, but also possible, that the content of our lessons can be relevant in terms of the most recent language developments to the day or even the hour of classroom instruction. Technology makes such immediate access to languages around the globe possible.

However, the proliferation and rapid evolution of the types of technology available to us with potential language teaching applications can be both confusing and intimidating (DuBravac, 2013). As a result of these advancements in technology, a plethora of articles and edited volumes have been devoted to detailing how various forms of technology might be utilized effectively for language instruction (e.g., Walker $\mathcal{E}$ White, 2013). Unfortunately, these materials and research are often outdated before being published because of the quick pace at which technology advances. Further adding to the complexity of the situation is that language teachers need to be well versed in understanding both why various technologies might be of benefit for language instruction as well as how they might be employed to realize such benefit. This paper will attempt to shed light only on the latter consideration.

To be certain, critical examinations into both areas are essential. Kern (2006) for example advises that "...it is important to ask what it means to use computers for learning and using a language, that is, to reflect critically on the social, cognitive, cultural, as well as educational implications" (p. 189). Crystal (2006) meanwhile offers us both a warning and some encouragement by stating, "if the Web holds a mirror up to our linguistic nature, it is a mirror that both distorts and enhances, providing new constraints and opportunities" (p. 206).
But have we been carried away by the opportunities technology might provide for language teaching and have we failed to fully consider and address how technology might alter our unenhanced linguistic realities? Crystal offers an interesting observation on the intimate relationship between technology and language teaching and learning by remarking " $\ldots$ it is in relation to foreign-language pedagogy that the most searching discussions have taken place [for utilizing technology], along with some innovative and effective practices relating to both teaching and learning" (p. 265). However, in this close relationship between technology utilization and language teaching and learning there is no explicit discussion as to how Crystal's previously mentioned distortions caused by technology are being addressed and overcome.

Based on these developments, it can be argued that examining specific forms of technology frozen in a particular developmental state and suggesting how they could be, or have been, employed successfully in language classrooms, as well as suggesting innovative and effective practices for technology which do not explicitly detail how they deal with the distortions technology can cause, are not sufficient by themselves to adequately support and guide language teachers' utilization of technology in their classrooms. Therefore, an overarching framework for how to consider embracing all types of technology, current and future, in the language classroom, will be presented here; a framework which emerged from over a decade of language classroom observations.

\section{Methodology}

In the early 2000s, the researcher had the opportunity to begin working with language faculty at an institution of higher learning in a pedagogical support capacity. In this position, some language faculty were required to work with the researcher to fulfil university requirements, and other faculty sought out the researcher to provide pedagogical assistance. Support typically came in the form of a pre-observation meeting to discuss the language classroom context, an in-classroom non-participant observation including the collection of student 
feedback, and a post-observation follow-up meeting with the faculty member which included observation and student feedback data debriefs.

The researcher went on to become a language faculty member at another institution where the researcher continued to offer pedagogical support for language faculty. This process continued across several more institutions and faculty roles. It should be noted here that how technology was applied by these various language teachers was not necessarily the primary purpose for these observations. However, the more observations that were made, the more it became apparent that what appeared to be the more successful uses of technology in language classrooms had similar features in common.

In total, observations of language classrooms continued for more than a decade with the researcher continuing to offer pedagogical support for language faculty. In all, observations of language teaching faculty occurred across nine institutions of higher and secondary education in three countries, and involved approximately 100 language faculty, teaching more than 12 different languages. It is from that combined observational data that the 3D system for embracing technology being presented here emerged.

\section{Proposing a 3D Approach}

In terms of the possible successes with technology that can be achieved in language teaching and learning, Kern (2006) perhaps put it most aptly by commenting that "...it is not the technology per se that is effective or ineffective but the particular ways in which the technology is used" (pp.188-189). Such thinking echoes, in some ways, what Politzer (1970) remarked about the teaching behaviours of language teachers over four decades earlier, "the 'good' teacher is the one who can make the right judgment as to what teaching device is the most valuable at any given moment" (pp. 42-43).

However, with so many judgments to be made at any one moment in the language classroom, what are language teachers to do in terms of how they might consider, and utilize, technology for language teaching and learning purposes? In an attempt to provide a useful framework for language teachers to achieve that end, a 3D system for embracing technology will now be offered. This system is comprised of three elements: 1) Directional, 2) Developmental, and 3) Decisive. These elements will now be presented and explained in turn.

\section{Directional}

Here directional means that the technology being utilized, as well as the content being accessed by the particular form of technology, should be directed specifically at the learners in the classroom. Put another way, when technology is intentionally aimed at students, linked somehow to their contexts and realities, students typically respond positively. From observational data, it was apparent that classroom uses of technology which were embedded in a rich context and sometimes even projected into the actual physical classroom spaces with some kind of representation of the content elements being resourced by the technology application typically resulted in more student involvement as well as more kinds and types of student language production.

An example of the directional element of the 3Ds might deal with the introduction of vocabulary. Say an instructor is teaching a lesson on food and eating. The introduction of cutlery, plates, dishes, cups, glasses, and so on in the lesson can be supported through a selection of rich images in a PowerPoint (or related technology) with the visuals appropriately labelled in the target language. How much more engaging would it be then to have, in addition to the aforementioned visuals, supported by various technologies, the actual items themselves in the classroom for students to touch and manipulate? After all, students are in a language classroom not a dining hall. Such intentional projection of technology from out of the projection screen and into the physical classroom space had a powerful impact on enhancing student interest and providing additional contexts for language production based on observational data. Furthermore, with advancements and increases in modelling and toys, even the largest items one might imagine, from airplanes to trains to even buildings, can be brought into the language classroom in miniaturized form. Such visual and physical representations of the items being taught in the language classroom offer 
additional opportunities and contexts for learners to engage the content and produce language.

Heift and Chapelle (2012) make it clear that language teachers and learners of today now operate in new and different realities and suggest that "the precious, and in many contexts rare, face-to-face conversations that formed the basis of important theoretical perspectives on SLA have been supplemented, diversified, and extended beyond the physical boundaries that separated learners from their target language in the past" (p. 565). Fisher (2009) further captures what the directional component of the 3D approach is aimed at in commenting on one of the benefits of technology, "I think that's where it's most useful to us because we are not in France, we are not in Germany. But with the internet you kind of go there, so that's very helpful" (p.72).

But is just going there enough for what language teachers want to achieve? Surely it is important that students need to be somehow prepared to ease the technologically enhanced classroom journeys they take with technology, making them meaningful, focusing on the experiences somehow. Therefore, the directional component of this framework attempts to address the distortion technology causes with space by providing a grounding and lessoning of the perceived distances covered by offering connections with the familiar through explicit comparative explorations and realia enriched encounters. That is to say, don't suddenly drop language learners off in Bogotá by showing an infomercial about the capital without providing contextual and comparative information, and a selection of realia which can make the capital come alive by creating links between the language and the learner beyond those afforded by technology alone. The impact of realia as a language learning aid should not be easily discounted (see Kelly, 1969).

Another example drawn from observations might be to show an online video of a currently popular musical band from the target-language culture. Playing the music video of this band in the classroom is certainly a viable option. But are we taking full advantage of the rich background information about this band by just playing the video? Surely we might consider sharing the ages, interests, and hobbies of the band members. What about sharing how many albums the band might have sold, where they have held concerts, and then comparing those facts to a musical band of similar style from the students' home culture? It is the belief of this researcher, based on the observational data, that such explicit tagging, the purposeful connection to a range of supporting content, makes a much more memorable experience and provides students more opportunities to negotiate with the language on a number of different levels.

In sum, the directional element of the 3D approach offers teachers an approach for addressing the distortions in space caused by technologies used for teaching by asking teachers to consider how they are making the students' journeys with technology more accessible. It was by far the most observed of the 3Ds over a decade of observations and perhaps speaks to an innate understanding which many language teachers have that you cannot ask students to suddenly go to a different, real or imagined, location within the confines of the language classroom without providing rich, layered, meaningful, and directed contexts to support them in their learning.

\section{Developmental}

The developmental element of the 3D system captures the resistance some observed teachers had toward accepting the limitations technologies were imposing on aspects of the language they were in the process of teaching. Very few technologies have been developed specifically with language instruction in mind. Take the television, typewriter, and camera as examples. No one would say that these technologies were developed specifically for language teaching and learning. Yet, over time, presenting moving images with sound, writing that can be used repeatedly, and photographs have been incorporated into various approaches employed by language teachers. Today language teachers still find themselves employing technologies originally intended for something besides language instruction in their classes. So instructors make do, as they have historically, with what these newer technologies can offer in terms of instructional possibilities. Sometimes teachers are even being pressured into using technologies for no apparent reason as Wright (2012) remarks: 
The current information revolution inevitable affects formal education...These new technologies do not simply exist, waiting neutrally to be used, either. Teachers often experience intense pressure to adopt technological solutions to learning problems, even when a case for adoption has not been made. (p. 64)

However, despite these issues, some instructors have not forgotten that there are technologies which process language in ways that are independent of how an actual person would process the same language. It is interesting to contemplate Hoopingarner's (2009) remark that:

There are fundamental differences in the way that computers and humans process language, and it is for this reason that we cannot be sure that computers will ever be able to communicate with humans, using human language, in a human-like way. (p. 230)

So the developmental element of the 3D approach addresses how technologies distort the actual language being taught in the classroom. Teachers observed who embraced the developmental element of the 3Ds make explicit efforts to take language out of the technologies in which it had been delivered up to that point and freeing the language back into its most natural state-unaltered language for use between people without technological mediation.

Representative examples of the developmental element of the 3Ds approach based on multiple observations in language classrooms at various institutions occurred with technology when an audio segment was too fast, or too slow, or beyond the current linguistic levels of the students. It also occurred when a video had subtitles but they weren't wanted or didn't have subtitles and they were needed, when language in a video was open to multiple possible interpretations by students, or when language processed by technology did not provide the kind of language meanings the teacher was after. In these situations, teachers would often stop the technology being used and bring the language just covered by technology into more specific focus, frequently by providing additional resources. The result was often that the teacher would first clarify the language point or points under scrutiny and then have the students actively use that language, be that through speaking or writing.

At this juncture, it would be beneficial to share how Widdowson (2002) unpacks what our subject can be understood to be:

It is French, German...as a foreign language. That is our subject, and that is what teachers need to know. Such a subject needs to be designed so as to counter the foreignness and compensate for it, so as to localize the language to make it learnable. Classroom language is bound to be contrived in one way or another: the question is what kind of contrivance will engage the interests and dispositions of learners, and so meet the local conditions for learning. The teacher's responsibility is to create these conditions by artifice. (p. 78)

The conditions of artifice which Widdowson suggests must be worked at so they can be consistently realized in the language classroom. This is certainly true when attempting to create these conditions with technology as well. If the language embedded in technology was linguistically beyond students and not modified for students by the teacher in some way, student uses of that language would be unintentionally stiff, because they were just parroting what they thought the language was for. Meanwhile, and this was encountered several times, if the language contained in technology resources was overly manipulated pedagogically (sometimes publishers do this in their online or DVD materials which support their textbooks) students can feel these materials are disingenuous and then intentionally produce stiff and awkward language to mock the very materials specifically prepared for them.

The teacher has an important role to play in all of this and returning to Widdowson (2002) we find that role described:

A teacher's knowledge of the language subject means knowledge about the language, and how it can be managed to make it learnable, which in turn involves managing the learners to induce them to learn. This management can take many forms... (p. 80) 
So a teacher's management of the language and the learners in the classroom does not stop when a technology supporting language teaching and learning is being employed. The teacher has to continue to manage the language being supported by technology so that it is still learnable.

In closing, the developmental element of the 3Ds approach targets the potential restrictions technology could impose on language being presented in the classroom and allows teachers the ability to move past such limitations to offer unconstrained language in more natural linguistic settings for students to engage in and interact with. This is realized by teachers being willing to provide extra support, clarification, and potential modification to language provided through technology. The developmental element then specifically addresses the distortions in language that technology can cause. The developmental element of the 3D approach was the second most observed of the 3Ds and had a noticeable positive impact when employed on the types and kinds of language production students attempted, and were willing to attempt, in the classroom.

\section{Decisive}

The final element of the 3Ds approach is decisive. Decisive refers to how some observed language teachers dealt with distortions in time caused by technology. In this domain, it has been suggested by Fisher (2009) that "better pupil motivation through improved pace and quick changes of activities..." (p.71) can be realized through the utilization of technology. But what if technology is actually working against that goal? What if technology actually caused the pace of the classroom to grind to an awkwardly slow speed as is often the case? What if there is a technology glitch and its continued application in the way it was originally intended by the teacher is now proving difficult to realize?

Many observations of technological applications in language classrooms would drag on for inordinate amounts of time and settle into patterns of language repetition and use which did not seem conducive to meaningful language learning. These distorted instances of time use fall outside of what might be considered typical classroom progressions though content and they frequently resulted in what appeared to be a stilted and awkward learning experience for students. This seemed to be primarily due to the fact that a consistent pace could not be established in the class which resulted in there being little cohesion between and within lesson segments.

Some language teachers who were observed would display an awareness of the potential negative impact some uses of technology could have on pacing in the classroom and as a result would move between the technological applications and classroom-based student interactions at regular intervals. This frequent moving in and out of the technology enhanced the liveliness of the language, making it more pertinent in the moment for students in the classroom. An example of this would be when a teacher sees that the time students require setting up between group presentations being offered in the target language using technology is taking longer than anticipated and knows that something needs to be done. The teacher decides to review with the class what the last group just presented, have the students predict what might be some elements contained in the talk about to be given by the next group, and identify any common areas that might be found between both group presentations. By doing this, a pace is established and links between lesson elements achieved.

To summarize, the decisive element of the 3Ds focuses on how language teachers can take steps to regulate distortions in time caused with technology by moving deftly in and out of the technology resources being applied so language liveliness will be further enhanced, not reduced. The decisive element was the least frequently observed of the 3Ds and may speak to a belief by some language teachers that when technology is being used in the classroom it is a time for them to do something besides teaching.

\section{Results and Discussion}

The 3D approach finds additional support in the fact that it resonates with findings from other recent sources and research. Morgan and Olivares (2012) 
have a book on successful strategies for using technology for teaching. What is so fascinating about this text is that the content is based on the experiences of award-winning teachers' uses of technology. If teachers who have been proven to be successful with using technology for teaching are sharing chapters in this text with the titles "promoting engagement," "providing access," and "becoming more efficient" as entry points into using technology effectively for teaching, then it would seem that there are connections between this text and each of the elements in the 3Ds. What is directional but one way of enhancing engagement and motivation by directing the technology being used at the learner? Isn't developmental focused on providing the learner access to language at an appropriate level? Finally, could decisive be understood as being efficient with using technology in the classroom? Such connections, however tentative, between this text and the 3Ds lend some weight to the 3Ds being part of a larger understanding of what using technology successfully for teaching means.

Meanwhile, Kern (2014) in his examination into the Internet for foreign language instruction offers questions which speak almost directly to the 3Ds presented here:

How do linguistic elements interact with nonlinguistic elements to produce particular meanings? How have conventional semiotic resources been appropriated, adapted, or recontextualized for individual or collective purposes? How are time (e.g., rhythm, timing) and space (e.g., visual layout, movement) used to create particular meanings or effects? (p. 353)

Certainly the 3D approach offers a great deal for language teachers to contemplate and consider in relation to their possible uses of technology for language teaching and learning purposes. Such an approach could certainly be of benefit for both experienced and novice language teachers. Gruba and Hinkelman (2012) have argued for uses of technology by language teachers which this approach would be aptly suited to support, in a way freeing teachers to pursue these higher level goals and suggest that "experienced teachers must gain a better understanding of the opportunities afforded by multidimensional technologies, and students training to teach languages must begin to both imagine and implement innovations that arise with such opportunities" (p. 156).

\section{Pedagogical Implications}

The 3D approach outlined in this paper highlights how some teachers took steps to maximize both the effectiveness and impact of their uses of technology in the language classroom by directing it at their students, not allowing artificial limitations to be imposed on the language they were teaching, or tolerating awkward progressions of how time unfolds through technology during class. The positive actions some teachers took in these regards emerged from the observational data and came to be called Directional, Developmental, and Decisive elements, known collectively as the 3Ds. At a still deeper level, however, the use of the letter $D$ in this approach was very intentional and should also be understood as representing distortion. This is because the 3Ds represent the three most commonly identified distortions technology had on language classrooms based on observational data—distortions in space, content, and time.

It terms of possible pedagogical applications, the 3Ds offer a potentially rich and rewarding pretechnology use checklist for language teachers to go over before utilizing any technology they might be considering for classroom applications. Representative questions for such a checklist might include the following: How will this technology impact the classroom space and how will that potential conceptual change in space be received by students in the classroom? How will the language being taught with technology be altered or changed by that technology? And how will technology influence the times required to teach, and for students to learn and use, the language embedded in this technology?

To summarize, it is not the intention here to insinuate that any aspect of quality language teaching boils down to following a checklist. However, what is being forwarded is that, based on over a decade of observational data, the questions suggested 
above can aid language teachers in deepening their understandings toward how the technologies they are utilizing in their classrooms are functioning and for what perceived purposes.

\section{Conclusions}

It is worth noting that across a decade of language classroom observations, very few teachers exhibited all of the 3Ds described here. Many teachers took advantage of one of the 3Ds and several made use of two. It is with this in mind that the 3Ds approach has been presented for language teachers to consider utilizing in their own applications of technologies for their specific teaching realities and contexts. It is hoped that this approach will provide teachers with a resource which compels them to explicitly consider issues of space, content, and time when employing any technology for language teaching and learning.

Evolutions with how technologies impact classroom learning environments will undoubtedly continue. The 3D approach presented here offers language teachers a set of lenses through which they might further critically examine and explore their own practices with regards to technology use for language teaching and learning. In the end, the language teaching professional must always remain cognizant of the impact and influence of the technologies used for language instruction have on the language teaching and learning environments in which they operate and build in steps which will not only minimize, but also potentially take advantage of, any distortions these technologies might cause.

\section{References}

Crystal, D. (2006). Language and the internet (2nd ed.). Cambridge, UK: Cambridge University Press.

DuBravac, S. (2013). Technology in the L2 curriculum. Boston, MA: Pearson.
Fisher, L. (2009). Trainee teachers' perceptions of the use of digital technology in the languages classroom. In M. J. Evans (Ed.), Foreign language learning with digital technology (pp.60-79). London, UK: Continuum.

Gruba, P., E Hinkelman, D. (2012). Blending technologies in second language classrooms. England: Palgrave MacMillan.

Heift, T., \& Chapelle, C. A. (2012). Language learning through technology. In S. M. Gass \& A. Mackey (Eds.), The Routledge handbook of second language acquisition (pp. 555-570). London, UK: Routledge.

Hoopingarner, D. (2009). Best practices in technology and language teaching. Language and Linguistics Compass, 3(1), 222-235.

Kelly, L. G. (1969). 25 centuries of language teaching. Rowley, MA: Newbury House.

Kern, R. (2006). Perspectives on technology in learning and teaching languages. TESOL Quarterly, 40(1), 183-210.

Kern, R. (2014). Technology as Pharmakon: The promise and perils of the internet for foreign language education. The Modern Language Journal, 98(1), 340-357.

Morgan, R. K., E Olivares, K. T. (Eds.). (2012). Quick hits for teaching with technology: Successful strategies by award-winning teachers. Bloomington, IN: Indiana University Press.

Politzer, R. L. (1970). Some reflections on 'good' and 'bad' language teaching behaviors. Language Learning, 20(1), 31-43.

Walker, A., E White, G. (2013). Technology enhanced language learning: Connecting theory to practice. Oxford, UK: Oxford University Press.

Widdowson, H. G. (2002). Language teaching: Defining the subject. In H. Trappes-Lomax $\mathcal{E} \mathrm{G}$. Ferguson (Eds.), Language in language teacher education (pp. 67-81). Amsterdam, NL: John Benjamins.

Wright, T. (2012). Managing the classroom. In A. Burns E J. C. Richards (Eds.), The Cambridge guide to pedagogy and practice in second language teaching (pp. 60-67). Cambridge, UK: Cambridge University Press. 